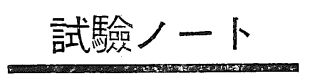

\title{
海藻油脂及び㠊蠟に關する二, 三の實驗
}

\author{
片山龍 郎* ・王隆 之*
}

I. 海藻油脂の数種に就いて

試料試料はホンダワラ, アラメ，カジメ，ツノマ 夕（探集期，昭和 24 年 6 月; 探集地; 若松市北海岸, 形態，未枝部）と最寄りの市販のワカメ，コンブ，ヒジ キに就いて實驗を行つた。な报初めの 4 者は採集後よく 水洗して風乾狀態としたものを使用した。

方法海藻の含油量が少いためと裝置として便宜上 $1 l$ のフラスコとコンデンサーとを用いて, 抽出を行つ た。試料を每回 $50 \mathrm{~g}$ 取つて成るべく細かく截斷し（約 $1 \mathrm{~cm}^{2}$ 位) 溶媒の滲透を容易にした。溶媒にはエーテル $500 \mathrm{cc}$ を用いたが，その抽出時間は約 $10 \mathrm{hr}$ とした。 各試料每江抽出は數回行い，各海菭油脂を充分沉採集し た。

結果 試料海藻の酸價, 鹼化價支び沃素價(Wijs 法) を測定し，且海藻油脂抽出率（％) を附記した。

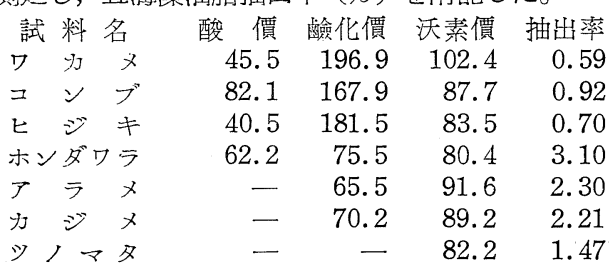

考察海澡油脂の酸價は非較的大であることを認め た。これは試料を風乾するためやや長時間放置したため その間に分解したとも考光られる。襝化價について考察 するとワカメ，コンブ，ヒジキは陸產植物油脂のそれと 大體同じであつたが，ホンダワラ，アラメ，カジメは非

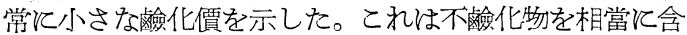

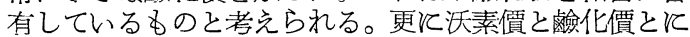
ついて檢討すると，ワカメ，コンブ，ヒジキの含有油脂 は明か、不乾性油飞屬し，その他のものはかなりの不純 物を有するため本來の海藻油脂の沃素價よりるかなり小 さい值を示した。それねも拘らず 80〜90 の沃素價を示 したのはその中とかなりの高度不飽和脂肪酸誌を含有し ているものと思われる。

\section{II. 櫨蠟の生物化學的一實驗}

試 料

1）谑樹 伊吉㖸, 約 80 年の古木, 樹勢旺盛, 高さ 約 $8 \mathrm{~m}$, 周圍約 $1.5 \mathrm{~m}$, 結實量年約 $60 \mathrm{~kg}$

2）採集場所 福岡縣築上郡山田村大字川內字平原

3）探集期日

管 1 回 昭和 24 年 7 月 20 日

管 2 回同年 8 月 20 日

篇3 回同 年 9 月 21 日

箳 4 回同年 10 月 19 日

篇 5 回同年 11 月 20 日

篇6 回同年 12 月試料なし

方法㠊實の抽出に當つては元來との果皮と核部よ りの油脂分はそれぞれ成分を異にするから兩者を分離し て抽出するのが至當であるが，本實驗では㠊實の結實か ら成熟するまでの間の生物化學的變化を實驗するのが目

*九州工業大學工業化學科教室（福岡縣戸畑市中原）
的でめるためと且.7月分の試料が結實したばかりで中果 皮と核部とに分離することが困蜼なために各月分の試料 は全部とれぞれ网者を分離せずに全含油量として抽出し て油分，酸價，鹼化價等を測定した。抽出器にはンック スレーの裝置，抽出劑にはエーテルを用いた。な招抽出 用試料は水分を含さから適宜粉席して空氣浴中に入れて $100 \sim 5^{\circ} \mathrm{C}$ で約 $2 \mathrm{hr}$ 乾燥させる必要があつた。この祭 7 月分の試料のみは充分に粉碎することができたが， 8 月以降の試料は核部の粉碎が充分にできなかつたから荒 碎きして $5 \mathrm{hr}$ 抽出して後一旦中止し乞れる取り出して 更に粉碎して後 $3 \mathrm{hr}$ 抽出を續行し合計 $8 \mathrm{hr}$ 抽出を行 つた。從つて7月分の試料は最初から $8 \mathrm{hr}$ 抽出を行つた。

結果 (1) 水分文び油脂含有量

$\begin{array}{ccrr}\text { 誈料月別 } & \text { 色 } & \text { 水分\% } & \text { 含油量\% } \\ 7 & \text { 濃綠 } & 10.92 & 2.28 \\ 8 & \text { 綠 } & 12.78 & 19.60 \\ 9 & \text { 綠 } & 8.21 & 22.69 \\ 10 & \text { 茶褐 } & 9.55 & 24.99 \\ 11 & \text { 茶褐 } & 7.11 & 31.37\end{array}$

（2）酸價，睯僉化價及びエステル價

$\begin{array}{cccc}\text { 試料月別 } & \text { 酸 價 } & \text { 鹼化價 } & \text { エステル價 } \\ 7 & 65.75 & 160.8 & 95.05 \\ 8 & 25.13 & 202.8 & 176.97 \\ 9 & 17.74 & 200.7 & 182.96 \\ 10 & 5.52 & 199.8 & 194.28 \\ 11 & 7.48 & 197.6 & 190.12\end{array}$

考察 1) 㠊實は成熟するとつれて水分が減少し油 脂含有量は最初の 7 月から 8 月に涉つて急激に增加す。

2) 酸價は成熟する程減少し 10 月～12月になると殆 んど一完となる。な打酸價と油脂含有量とを併せ考劣る と油脂分は 7 月から 8 月に涉つてその變化率は最大であ る。即ちこの持期は櫨樹の發育の最も旺盛な時であつて その後は㒖かに 3〜6\% 增加しているに迥ぎない。これ から推察すると 7 月分の試料の 65.75 とい5酸價はそ の頃は同化作用により遊離脂肪酸が生成れるのみでグリ セリドにならず，その後月を逐つて次管にグリセリドが 生成し酸價は大いに減少していくよ5飞思われた。從つ てその酸價の減少度と油脂含有量の增加度とを圖表で表 わすと對蹠的であつた。

3）敵化價については 7 月分の試料の值は小さく，そ の他の月の試料は大體一定しているよ5に思われるが更 に仔細に檢討すると8月から 11 月へと進むにつれて幾 分減少している。これは中果皮より採取した木蠟の㓺化 價は 205 211 であつて，㯫核油のとれは 189〜193 で あることを考劣ると，本實驗に执いては試料は木蠟と㯭 核油との混合物であるから月の進むてつれて櫨核油の制 合が中果皮の木蠟分のそれよりる增加しているものと考 えられる。文實際に每月㯭實を觀察すると月の進むにつ れ核の硬さと太さとが增すから實驗結果とこの考察とは よく合致することになる。

4) 以上の結果より櫖實の最適の採集時期は大體11月 中旬であることを知つた。

(昭和 28 年 2 月 9 日受理)

註）辻本满丸，東工試報， 21，6 (1926) 